University of Nebraska - Lincoln

DigitalCommons@University of Nebraska - Lincoln

August 2008

\title{
Gender and the political economy of knowledge
}

Ann Mari May

University of Nebraska-Lincoln, amay1@UNL.edu

Follow this and additional works at: https://digitalcommons.unl.edu/econfacpub

Part of the Economics Commons

May, Ann Mari, "Gender and the political economy of knowledge" (2008). Economics Department Faculty Publications. 35.

https://digitalcommons.unl.edu/econfacpub/35

This Article is brought to you for free and open access by the Economics Department at DigitalCommons@University of Nebraska - Lincoln. It has been accepted for inclusion in Economics Department Faculty Publications by an authorized administrator of DigitalCommons@University of Nebraska - Lincoln. 

ina (London and New York: Routledge, 2008), Chapter 13; pp. 267-285. Copyright (C) 2008 Ann Mari May. Used by permission.

\title{
Gender and the political economy of knowledge
}

\author{
Ann Mari May
}

\section{Introduction}

The importance of increased levels of education in improving the status of women throughout the world is well established. Higher levels of education are associated with lower birth rates, higher incomes, and greater autonomy for women. In fact, it has been argued that education is a fundamental prerequisite for empowering women in all spheres of society (Lopez-Claros and Zahidi 2005: 5).

In the last third of the twentieth century, women have made particularly significant strides in many countries. For example, UNESCO reports that women's share of enrollment in higher education in Switzerland rose from 3 per cent in 1985 to 43 per cent in 2000 and in France, women's share of enrollment increased from 50 to 55 per cent. Women's share in Latin American colleges and universities over the same time period rose from 43 to 47 per cent in Chile, and 44 to 54 per cent in El Salvador. In India, women's share has risen from 30 to 39 per cent. ${ }^{1}$ While certainly not universal, this trend towards gender balance in student enrollment is remarkably similar in a large number of industrialized countries throughout the world. ${ }^{2}$

The increase in the participation of women as students is now beginning to reach the highest levels of educational attainment. The Nordic Research Board (NORBAL) reports that women received 46 per cent of doctoral degrees awarded by universities in the Nordic and Baltic countries in 2005 - up from 28 per cent in 1990 (NORBAL 2005: 3). In the United States, in 2002, for the first time in American history, more American women than American men received doctorates from US universities (Hoffer et al. 2003).

The increase in representation of women as students in higher education has not, however, produced a proportional increase in the representation of women as faculty. For example, in 2000, women constituted only 4.4 per cent of faculty at Austrian universities, 11 per cent of faculty at German universities, 12 per cent in Swedish universities, and 10 per cent in UK universities (Zimmer 2003: 9). In 1995, UNESCO reported that in Norway and Canada women constituted only 21 per cent of faculty, and in the US only 31 per cent of faculty (UNESCO 2005).

While some countries, such as Sweden, Canada, and Norway, have implemented programs to increase the representation of women faculty, these 


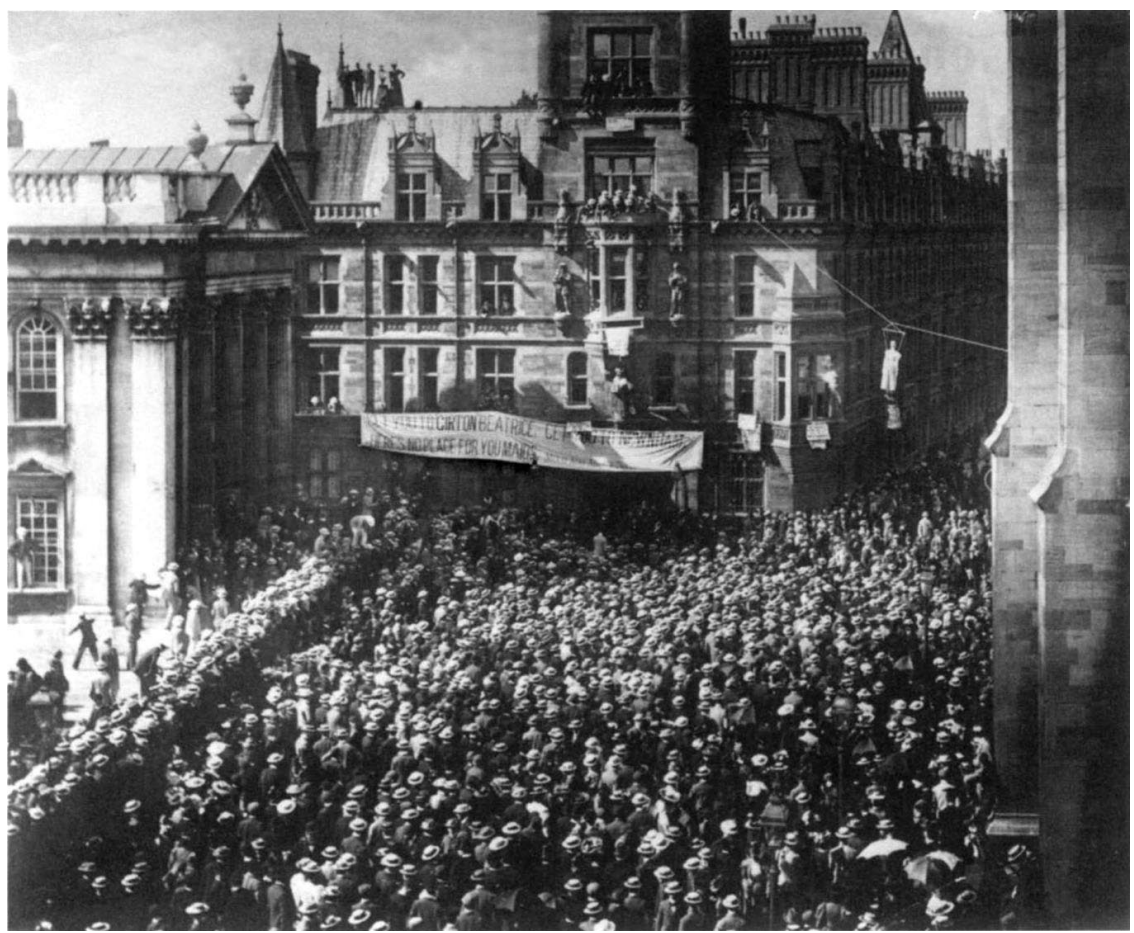

Figure 1. Students protest the introduction of women at Cambridge University, 1897.

programs have often been strongly criticized by male faculty and thrown out by (mostly male) courts. In 1995, the Swedish government created 32 posts at full professor level, the so-called Tham professors, especially for women. Men were allowed to apply but would only be given the job if there were no qualified women. But in 2000, the EU Supreme Court turned down the Tham proposal, and the program is currently under debate in Sweden (Jordansson 1999). In 2000, the University of Oslo implemented a plan to improve gender diversity among faculty by reserving 12 full or associate professorships for female candidates. However, in January 2003 the European Free Trade Association Court ruled it illegal for the University of Oslo to reserve faculty positions for women. ${ }^{3}$

In describing the reaction of academics in Norway to the call for gender equality in higher education, Ms. Tove Beate Pedersen, head of the Secretariat for Women's Studies and whose job is to work with female recruitment said, "We have experienced stronger and more sophisticated resistance than we had expected. Vigilance and additional resources are necessary in order to increase female recruitment, and to integrate female perspectives and interests more effectively in academic life" (Ministry of Children and Family Affairs, Norway 2000).

The history of men's opposition to women's participation in higher education has been remarkably consistent across cultures and through time. From 
male students in Cambridge in 1897 protesting the presence of women students, to male faculty in the first years of the twenty-first century opposed to governmental attempts to redress the paucity of women as faculty, equity for women in higher education has seldom been uncontroversial.

Today higher education, like other sectors in society, remains gender segregated. Women continue to occupy the lowest ranks, work at the least prestigious institutions, and receive the lowest pay and least job security. As Jerry Jacobs has pointed out, in the US, while women have attained access to higher education more or less on a par with their male counterparts, they fail to benefit in terms of outcomes on par with men (Jacobs 1996: 154). Worldwide, while women have increasingly been accepted as consumers in the seminaries of learning, they continue to be marginalized and excluded as colleagues or writers of the canon - particularly at the research institutions from which the canon emerges. Their desire to participate as full citizens in the institutions of higher learning is often met with resistance.

This essay examines the institutions responsible for knowledge production, focusing on gender and the political economy of knowledge. We begin with an examination of gender politics and the higher learning through the controversy that came to be known as the querelle des femmes - the quarrel of the women. Through the querelle des femmes, we examine what is at stake in the higher learning and begin to consider the strategies that have been employed to maintain the patriarchy of knowledge. These issues are given formal theoretical consideration through the work of Thorstein Veblen. Engaging with and expanding the framework established by Veblen's The Theory of the Leisure Class (1899), we will examine higher education as an institution and consider the ways in which the social construction of gender is used to signify and maintain power relationships within higher education.

By examining higher education as an institution that responds not only to the internal imperatives of the agents involved in the production of knowledge, but also as an institution influenced in various ways by the broader culture, we gain insight into the reasons for women's limited inclusion and marginalization within the higher learning. Moreover, a more complete understanding of the higher learning as an institution allows us to better develop strategies for promoting a more equitable higher learning.

\section{The "Woman Question" and the higher learning}

In 1895, when women students from Smith College gathered on the day before commencement to celebrate Ivy Day, it was a ceremony rich with symbolism. Women students, dressed in white and carrying roses, led a parade through campus, which ended with the planting of ivy as a symbol of their lifelong connection to the college (Smith College Archives 2006). This sanguine picture masks another reality of women's other lived experiences in the higher learning - an experience evidenced most clearly by the photograph of Cambridge students taken in 1897 and found at the beginning of this essay. In this photograph, male university students are found protesting the 
presence of women students who were allowed merely to take classes but not to graduate with degrees.

The experience of women at Cambridge was not unlike the experience of women at hundreds of universities throughout the world. As "intruders" into the halls of ivy, women have been seen as a threat to the status of institutions, restricted in their use of facilities such as libraries and laboratories, constrained in their choice of courses, assumed to be lacking in intelligence and analytical skills, and told that their desire for equal treatment was a "bid for power" and that they were "never satisfied" (Tullberg 1998).

In Europe, the controversy over women and knowledge came to be known as the querelle des femmes or quarrel of the women - a centuries-long debate begun in the 1400s about equality of the sexes. In the nineteenth century, as biology surpassed prudence as the fashionable rationale for women's exclusion, debates about women's suitability for higher education came to be known as the "Woman Question." This debate continues today, with many of the same arguments being used to rationalize women's absence as producers of knowledge along with new arguments more suited to a market economy (May 2006). Yet, within the current debate remain the concerns raised over six centuries ago regarding the psychology of patriarchy and the gender politics of knowledge production.

\section{Querelle des Femmes}

While women today have an easier time being accepted as consumers than as colleagues, their role in the higher learning has long been contested and their access to knowledge production has been controversial for centuries. The debate, originating in the writings of Christine de Pizan and carried on by numerous women for over 400 years, represented an attempt to investigate and rebut the misogynistic view of women's inferiority constructed and reconstructed through 3,000 years of western culture. This misogyny permeated intellectual, religious, legal, and medical notions, as well as social and familial relations, during the European Middle Ages. The origin of this debate is worth examining because it tells us much about the psychology of patriarchy and the gender politics of knowledge production. Moreover, it foreshadows many of the arguments used to rationalize women's exclusion and limit their participation, strategies employed to preserve the patriarchy of knowledge, and difficulties that women would face in exercising their voice. Both Pizan's critique of patriarchal culture in The Book of the City of Ladies, and her treatment as a woman writer, present important lessons on the patriarchy of knowledge (Kelly 1982).

Pizan's critique of patriarchal culture found in City of Ladies, begins with the narrator reading the works of male authors from Aristotle to Matheolus. At first absorbing the view of women's inferiority espoused by "solemn scholars," the narrator then emerges from the "anguish" of "despising [herself] and all womankind" to articulate "a recognition of the man-made, misogynous nature of that claim" (Pizan [1431] 1982: 4-5 and Kelly 1982: 14). 
With the help of three allegorical women - Reason, Rectitude, and Justice the narrator learns to reject the authority of "grave dons, learned men, and men of sense," instead learning to explore women's experiences as authoritative in themselves (Astell 1730: 74). ${ }^{4}$

Demonstrating that education is central to identity, Pizan encourages women to educate themselves, not merely for practical reasons of administration of their household, but for more profound reasons as well: that they might come to see the authoritative view of men as non-authoritative (Pizan [1431] 1982: 153-4). As Pizan points out in the Epistre au Dieu d'Amours, "if women had written the books we read, they would have handled things differently, for women know they have been falsely accused." 5

Although the querelle used allegory, history, and empiricism to refute the claim of women's inferiority, the defense of women often focused on the psychology of men. In particular, these early feminists noted the importance of male competitiveness, explaining how men denigrated women out of fear that women would be found equal or even superior to them (Drake [1696] 1970: 11-20). ${ }^{6}$

The City of Ladies makes the argument for women's education and literacy, as Susan Schibanoff points out, recognizing that "as long as literacy remained an almost exclusively male prerogative, those token women who were allowed to attain this privilege did so at the risk of, among other things, their own identities" (Schibanoff 1983: 325). This view of the importance of access to knowledge recognizes the importance of the right of women to make knowledge claims, not merely to access the knowledge claims of men. In other words, women must have access to knowledge not merely to learn the canon, but to write the canon as well.

The City of Ladies provides us with an understanding of the why access to knowledge production is essential for women in terms of their identity, but the personal experience of Christine de Pizan as a writer also offers valuable insights on the costs of exercising voice and bears witness to the strategies that have been employed to preserve the patriarchy of knowledge. As a writer, Pizan was able to make a living for herself and her family, something few women of her time could do (Bell 1976: 175). However, she was allowed to do so only insofar as she wrote with a voice that was, as Schibanoff points out, "conventionally male-identified in subject, form, and genre" (Schibanoff 1983: 324).

In her early career, Pizan wrote largely uncontroversial poems and was able to function as a writer without significant criticism. However, when Pizan briefly attacked Jean de Meun for his antifeminist poem, The Romance of the Rose, she was marginalized by powerful men. Pizan was soon made aware of the "term of her tenuous condition" by three men who rose to de Meun's defense and who, according to Schibanoff, "reminded Christine that her male privilege was honorary and that they could and would demote her to female status if she persisted with her perverse feminist accusations against their 'beloved master'"' (Schibanoff 1983:325).

The critique of Pizan first took the form of mild rebuke. The authors express surprise that Pizan would offer such an inappropriate attack. Suggesting that she must have been put up to it by others, the authors discount her 
critique and minimize her independence of thought. When Pizan persisted, she was met with sexist insults as her opponents labeled her a "typically impassioned, arrogant, willful, foolish, and ignorant woman" (Schibanoff 1983: 325). In the end, her opponents excluded her altogether from their company. As Schibanoff so aptly describes it, "as a woman, she had proved herself to be unexceptional, hence unacceptable" (Schibanoff 1983: 325).

\section{Identity, agency, and the patriarchy of knowledge}

It is indeed revealing that the first, and perhaps most profound, lesson in The City of Ladies concerns identity and its construction. The construction of identity is particularly important in that it so strongly influences agency the ability of individuals to act within a context of being affected by institutions and history. While many modem discussions of the importance of education have focused on its pecuniary influence, the effect of education on agency is of profound concern as well. As Amaryta Sen and Martha Nussbaum have pointed out, education adds not only to human capital but to human capability, enabling women to exercise their legal rights as well as to strengthen their political and civic engagement (Sen 1999; Nussbaum 2000).

It is this relationship between identity and agency that lies at the heart of the patriarchy of knowledge and reveals, in a very fundamental way, the reciprocal relationship that exists between the patriarchy of knowledge and other patriarchal institutions in society. Higher education is particularly important as an institution in playing a pivotal role in shaping identity and generating constructions of reality that help rationalize inequalities and ultimately frame capabilities. Higher education, in this sense, both creates identity and offers a potent mechanism either for change or for maintenance of the status quo and is thus a crucial institution in society. While it is often argued that the "real world" has little in common with the higher learning, there is, in fact, a subtle and important relationship between the institution of the higher learning and other institutions in society. ${ }^{7}$

While scholars from a variety of disciplines examine the role of higher education in society, few have offered as provocative a look at the higher learning - a look that integrates important insights on women and the higher learning - than the economist and social philosopher Thorstein Veblen (May 1998). Veblen viewed the institution of higher learning in a way that later philosophers of science might refer to as the sociology of knowledge tradition. These philosophers, from Thomas Kuhn (1962) to Paul Feyerabend (1988), view the creation of knowledge as a social process that takes place in communities of scholars who are influenced by personal, social, and political values of the larger community. However, these later philosophers of science often failed to examine the gendered nature of socially situated knowledge. For example, they argued that science is often influenced by the agendas of those who fund research, but they failed to identify the ways in which the metaphors and conceptual frameworks used in science were themselves gendered. In other words, they were sensitive to the politics of knowledge claims but not the gender politics of such claims. 
Extending a gendered lens to the sociology of knowledge tradition, feminist philosophers of science such as Helen Longino (1990) and Sandra Harding $(1986 ; 1991)$ and others have shed light on the gendered nature of these communities and the ways in which perspective is determined by the location of the scholar. According to these scholars, women are often misrepresented in science because they are under-represented in science. Moreover, as Harding has pointed out, failure to recognize that observation involves subjective perceptions that are shaped by community and experience of the knower, limits our understanding. According to Harding,

Knowledge claims are always socially situated, and the failure of the dominant groups critically and systematically to interrogate their advantaged social situation and the effect of such advantages on their beliefs leaves their social situation a scientifically and epistemologically disadvantaged one for generating knowledge.

(Harding 1993: 54)

These feminist philosophers of science provide valuable insights on gender and knowledge production which, along with the insights of the political economist Thorstein Veblen, provide a useful framework for examining gender and the political economy of knowledge production. Veblen's insights found in The Theory of the Leisure Class, The Higher Learning in America, and in his little read The Nature of Peace, offer a unique view of the higher learning as an institution embedded in and impacted by society and a view in which gender is integral. They provide, as well, a provocative foundation for our examination of women and higher education today.

\section{Veblen and the political economy of knowledge}

As Veblen pointed out, institutions distribute power, and institutions of higher learning are no exception. While popular conceptions often explicitly argue or tacitly assume that higher education is a meritocracy in which the best ideas simply "bubble to the top," Veblen views the higher learning as an institution that distributes power (much like any other institution), is preoccupied with status maintenance (probably more than other institutions), is influenced by the values and imperatives of society, and occupies a critical position in manufacturing opinion. Veblen remains one of the few economists to provide an integrated view of the role of higher education that explicitly incorporates gender in his analysis in more than a trivial manner. In fact, from the introductory chapter of The Theory of the Leisure Class to his concluding chapter on the higher learning, there is little in Veblen's work that does not reflect a recognition of gender.

It is noteworthy that the introduction of Veblen's most famous work begins with a discussion of the emergence of the sexual division of labor $-\mathrm{a}$ distinction that Veblen saw as invidious. In the transformation from primitive savagery to barbarism - from largely peaceable to consistently warlike society - Veblen argues that the division of labor emerged in such a way that 
men were associated with activities such as war, hunting, sports, and devout observances, while women "held those employments out of which industrial occupations proper develop in the next advance" (Veblen [1899] 1998: 4 ). Thus, for Veblen, the modem distinction between industrial and non-industrial reflects the barbarian distinction between exploit and drudgery a distinction that coincides with the difference between the sexes and one in which those employments classified as exploit are considered "worthy, honorable, and noble," while those considered drudgery are thought to be "unworthy, debasing, [and] ignoble" (Veblen [1899] 1998:15).

In barbarian society, class distinctions emerge, bringing distinctions between a leisure and working class and an emphasis on ownership and pecuniary emulation. While every civilization cultivates esoteric knowledge that is considered to have intrinsic value apart from material considerations, the development and refinement of this esoteric knowledge "in its incipient phase" is a leisure-class occupation undertaken by men (Veblen [ 1899] 1998: 367). Although the pursuit of knowledge is taken by many to be an unadulterated search for "truth," it is itself a reflection of the "habits of thought" of the learned class who are, according to Veblen, "great sticklers for form, precedent, gradations of rank, ritual, ceremonial vestments, and learned paraphernalia generally" (Veblen [1899] 1998: 367). Veblen applies to the institution of higher learning the same framework of evolutionary change that he applies to other institutions. This broader framework is one in which institutions themselves, as well as institutional change, are presumed to reflect both ceremonial or backward-looking habits of thought related to stratified structures of status, as well as instrumental or technological values. Hence, the institution of the higher learning reflects both ceremonial and instrumental values in the internal structure or the habits and rituals of those who make up the corporation of the higher learning as well as the activities of those involved in the "matter of fact" activities of disinterested enquiry. Moreover, the higher learning reflects the influence of the broader culture, or what Veblen, at the turn of the twentieth century, called the pecuniary drift of the market system. For Veblen, the higher learning is a cultural artifact emanating from two impulsive traits of human nature - the instinct of workmanship and idle curiosity, and behavior that is, in a variety of ways and at various developmental stages, influenced by ceremonial behavior and the drift of pecuniary culture.

While the origin of the higher learning is rooted in the priestly and leisure class, there came to be a distinction between esoteric and exoteric knowledge, the former "comprising such knowledge as is primarily of no economic or industrial effect and the latter comprising chiefly knowledge of industrial processes of nature phenomenon which were habitually turned to account for the material purposes of life" (Veblen [1899] 1998: 367). Hence, the search for and preservation of esoteric knowledge constitutes the primary activities of those institutions associated with higher learning, while, in time, the existence of exoteric knowledge has come to be associated with what Veblen sometimes calls lower learning. However, in both institutions, ceremonial values are present to some degree. 
It was, of course, in the late nineteenth and early twentieth centuries that the advent of the market system, or what Veblen called the drift of pecuniary culture, began to exert its influence on the higher learning. Veblen speaks of the influence that emanates from the imperatives of a pecuniary culture that seeks, for example, to fit youths for careers in commerce. This motive drives the curriculum to prepare students to engage in the mechanics of commerce as well as to shape their values so that they appreciate, rather than question, existing arrangements. More to the point, according to Veblen, the purpose of higher learning is increasingly to fit youths of the leisure class for the "consumption of goods, material and immaterial, according to a conventionally accepted, reputable scope and method" (Veblen [1899]1998:370).

The drift of pecuniary culture directs a variety of activities so as to avoid the drop in enrollment and loss of goodwill in genteel circles and leads to the growth of a variety of "student activities" that Veblen sees as "sideshows to the main tent" (Veblen [1918] 1918: 74). Hence the growth in scholastic accessories - collegiate sports, fraternities, clubs, and exhibitions, all of which reflect the pandering of the corporation of learning to the business culture. The businesslike mentality of the corporation of learning and the resulting expansion of undergraduate education for that purpose, leads to the degradation of the higher learning and is decried because of its deleterious effect on the pursuit of knowledge. While even the sagacious Veblen could not have imagined the degree to which the growth of scholastic accessories would envelop the higher learning in the late twentieth century, it is perhaps his view of women and the higher learning that was most prescient.

\section{Women and higher learning}

As a by-product of the priestly and leisure class, the higher learning was taboo to women. Those few women who read widely, were allowed to exercise their new found voice to the extent that it did not challenge the patriarchy of knowledge. Yet by the mid-nineteenth century, women began to test this convention and call for admission into the halls of ivy both in Europe and in the US. By the 1860s, women students were already studying medicine in Paris. At the University of Zurich, one of the first universities to admit women as students, women they were enrolled as early as 1867 . By the 1870s, women were admitted into women's colleges in the UK. Also by that time Sweden and Denmark opened their doors to female students (Mazón 2003: 14-15).

In the US, although women's colleges began in the 1830s, it was the decline in male enrollment during the Civil War along with passage of the Morrill Act that spurred coeducation in the postwar years. The Morrill Act created a system of land grant colleges and universities, often in sparsely populated states - colleges and universities that could ill afford to forgo the potential revenue from female students. It was the rise of these new coeducational state universities that put increasing pressure on existing universities to admit women students thus raising the specter of women as faculty. In a very 
real sense then, the drift of pecuniary culture put pressure on state funded universities to open as coeducational. Women who were often viewed as unnecessary in established private schools, were increasingly viewed as necessary sources of revenue for fledging colleges in the west and mid-west.

When Veblen published The Theory of the Leisure Class in 1899, the University of Chicago where he taught, was coeducational, also retaining women on the faculty; yet, schools such as Harvard were notorious in their refusal to admit women. For Veblen, the attitude of schools towards women represented a measure of the degree to which these institutions departed from their priestly and leisure-class prerogatives and embraced the values of a modem or matter-of- fact standpoint (Veblen [1899] 1998: 375). Moreover, Veblen saw the reluctance of institutions to embrace women as a ceremonial vestment - a demonstration of class-worthiness and status. As Veblen puts it:

... the highest and most reputable universities show an extreme reluctance in making the move. The sense of class worthiness, that is to say of status, of a honorific differentiation of the sexes according to a distinction between superior and inferior intellectual dignity, survives in a vigorous form in these corporations of the aristocracy of learning.

(Veblen [1899] 1998:376)

Veblen's observation that the preservation of male domination should be viewed as a form of status maintenance was not missed on women activists at the time. Women were often well organized and set about targeting particular institutions such as Harvard in the US and Cambridge in England, to gain admittance for women most certainly with the knowledge that if prestigious institutions were to open their doors to women, other universities would emulate them (Walsh 1977; Tullberg 1998). Moreover, women in the US traveled to Europe to gain degrees when unable to do so in the US, often hoping to pressure universities in the US to open their doors to women.

In addition to noting concerns that the mere presence of women would "be derogatory to the dignity of the learned craft," Veblen points out that, to the extent that women were allowed the privilege of admission to the higher learning, it was felt that they should be constrained to acquire knowledge only in those areas that conduce "immediately to a better performance of domestic service" or to the "quasi-scholarly and quasi-artistic, as plainly come in under the head of a performance of vicarious leisure" (Veblen [1899] 1998: 376). That is, the ultimate purpose of education for women is to support the activities of her ultimate role in life - marriage and family.

That a particular type of education would be supported for women was true at the University of Chicago as well as elsewhere in the nineteenth century. In the same year that Veblen published The Theory of Leisure Class, Charles Eliot, noted president of Harvard, would argue that coeducation was "not possible in highly civilized communities," but women's colleges might be useful in encouraging religion and as schools of manners for young girls 
(Eliot 1874: 50-52). Therefore, while Harvard would offer "as many years as they wish of liberal culture in studies which have no direct professional value, to be sure, but which enrich and enlarge both intellect and character," the education of women should be different than that of men in that "their lives are different and their education should be different... Their education should take account of the life which is before them..." (Eliot 1874:53).

Likewise, even those few women who were able to secure degrees in areas not thought to be feminized per se, would find that their career advancement was to be attained only by abiding by this convention of separate spheres. For example, while Veblen was at the University of Chicago, not a single woman in the fields of Political Science, Economics, Anthropology, History, Psychology, or Sociology began her career as a junior faculty member and became promoted to full professor (Freeman 1969: 2). As Jo Freeman points out in her study of the University of Chicago during this period, Sophonisba Preston Breckinridge, who had received a doctoral degree in 1901 in the Department of Political Science and Economics and received her Doctor of Law in 1904, would find that she would be hired in neither law nor political economy. Her first appointment would be Assistant Professor in the Department of Household Administration. For her part, Edith Abbott, who taught sociology for six years without promotion, transferred to one of the so-called "women's departments" where she later became Dean of the School (Freeman 1969: 2).

The containment of women to the domestic sphere and to those areas of knowledge that serve to aid the performance of vicarious leisure was to be accomplished in subtle ways and, as we have seen, some rather not so subtle ways. However, the way that Veblen defines how these "feminine" and "unfeminine" fields are determined is both curious and compelling and may go far in understanding yet today in what areas women's work has been accepted and in what areas it is likely to be marginalized and forgotten. Specifically, Veblen identifies "unfeminine" knowledge as that which expresses the unfolding of the learner's own life, "the acquisition of which proceeds on the learner's own cognitive interest ... without reference back to a master whose comfort and good repute is to be enhanced by the employment or the exhibition of it" (Veblen [1899] 1998:376).

This would, of course, explain why it is that the study of women in the history of economics often dies with women. Not only is women's work overlooked through what has been called the "systematic misattribution," but it has been undervalued particularly when it is work that focuses on women (Dimand et al. 1995). As Robert Dimand points out,

... the "malestream" of the discipline did not care to read Abbott on Women in Industry, Breckinridge on Women in the Twentieth Century, Campbell on Prisoners of Poverty, Gilman on Women and Economics or McMahon on Women and Economic Evolution for the same reasons that male economists wrote little on the economic experience of the female majority of the population.

(Dimand et al. 1995:7) 
Scholarly work was masculine business and rightly concerned itself with the unfolding of the learner's own life, the acquisition of which proceeds on his own cognitive interests. ${ }^{8}$

Veblen's description of "unfeminine" (masculine) knowledge is particularly apt as it is a description that emphasizes independence not dependence - a distinction that, at its root, reflects a highly gendered notion of knowledge production and one that was long used as a foundation to argue against women's inclusion in the higher learning. From the philosopher Johann Erdmann in Germany to G. Stanley Hall in the US, the "Woman Question" in higher education would often end in arguments about women's capacity for independent judgment and ability to master the subjects while male attributes and metaphors were invoked to describe the characteristics of academic citizenship (Mazón 2003).

As Patricia M. Mazón so carefully describes, the German system of higher education in the nineteenth century, which served as a model for the modem research university throughout much of the world, viewed the academic enterprise as a community of scholars perpetuated by an apprentice system aimed at cultivating independent judgment and resting upon "masculine images of power and appropriation" (Mazón 2003: 37). As Erdmann saw it, the student's task was to mature by working his way up the ladder of knowledge first learning as a school boy, then studying as a university student, and finally pursuing knowledge as an academic scholar (Mazón 2003: 37). Comparing the relationship of a student to his discipline as a marriage of sorts, Erdmann envisioned that "true devotion to the subject of intellectual love" consisted not of submission but "mastering it and winning power over it" (Mazón 2003: 38). That women would hardly be viewed as scholars in such an enterprise is not surprising.

As the mechanism for training students to become faculty in the higher learning, graduate work was especially troublesome terrain for women. Just as undergraduate education was to be a bridge between childhood and adulthood for young boys, graduate work represented a bridge between learning as a student and generating knowledge as a scholar. As consumers in the academic enterprise, women were far less menacing than as potential colleagues and it is the political economy of this location that created an additional layer of difficulty for women.

In the end, it was the fear of women as colleagues and fellow professionals that sustained the controversy of the "Woman Question." The issue of women's role in the higher learning could not be settled without some discussion of what careers women would pursue at the conclusion of their education. Women as well were focused on the career question and pushed hardest to enter medical schools with this career in mind. It was the competition from women doctors that stiffened the resolve of medical faculty in denying access to medical education for women (Mazón 2003: 95). Pecuniary drift had its impact on women's access to the academy as men feared competition from women. 


\section{Gender and knowledge production today}

The sweeping transformation in industrial society that accompanied the rise of the market system brought a fundamental transformation in the higher learning itself. Universities, particularly elite universities, became the gateway to professions in both politics and commerce while the pecuniary drift of industrial society changed the institution of the higher learning itself. Thus, universities played a central role in the formation of status in society. It is little wonder then, that the expansion of higher education brought increased competition within the higher learning along with new efforts to maintain status within the institution of the higher learning.

Veblen's observations on the relationship between the preservation of status and the representation of women as students at the turn of the century continues to resonate in higher education today in two distinct ways. On the level of faculty representation, there remains a close relationship between the status of the university and the representation of women. As a recent study of Carnegie I Research Doctoral Schools in the US confirms, representation of women as faculty is inversely correlated with status measures such as Barron's Profiles of American Colleges. While women in the most competitive category had an average of 27 per cent female faculty, the representation of women in the less competitive grouping was 75 per cent higher than the most competitive group. As status rises, women are increasingly absent in the halls of those Ivy League schools. ${ }^{9}$

Where students are concerned, institutional attempts at status preservation through gender discrimination have become increasingly public. In a widely read editorial appearing in The New York Times, Jennifer Delahunty Britz, Dean of Admissions at Kenyon College, went on to discuss the reality of the admissions process at elite institutions (Britz 2006). Britz describes how these institutions often accept less qualified male students over more qualified female students in an effort to maintain a more equal gender balance in undergraduate enrollment. While not justifying the practice, Britz argues that this particular form of "affirmative action" for men reflects the impulse of colleges intending to preserve applications of both men and women which, it is believed, decline if the ratio of female to male students becomes too high. High status institutions feel compelled to preserve their status through gender balancing in enrollment.

The "domestication of women" in higher education is reflected in continued segregation both as students and later as faculty. Today, women continue to be segregated by fields in higher education. They are over-represented in the fields of English, education, library science, and the health sciences and under-represented in the fields of science and engineering. In 2002, women received only 18 per cent of doctorates in engineering and 16 per cent of doctorates in physics and astronomy while receiving 66 per cent of doctorates in education. In the social sciences, women receive 55 per cent of total doctorates, yet they receive only 28 per cent of doctorates in economics while receiving 60 per cent of doctorates in anthropology and sociology (Hoffer et al. 2003). 
The "domestication of women" in higher education reflects itself not only in field choice but in the distribution of tasks within disciplines (Levit 2001; Park 1996; Moore and Sagaria 1991). As organizational theorists have argued, gendered divisions of labor emerge in organizations - divisions that "carry characteristic images of the kinds of people that should occupy them" and replicating gender stereotypes that exist outside the organization (Kanter 1977). Within academe, a gendered division of labor exists such that not only is research valued more than teaching and service, but what constitutes good research, the science of discovery as Ernst Boyer would call it, is often identified with research that men do.

Moreover, as Shelly M. Park points out, the degree to which research is "tainted" by its affiliation with teaching also serves as a measure of its status. Peer review journals are valued more than conference papers which is akin to lecturing and articles in scholarly journals to be read by other researchers are higher in status than publishing a textbook to be read by students (Park 1996: 48). Conversely, those teaching activities such as teaching graduate courses, that are more closely associated with research, are higher in status than other teaching such as the teaching of undergraduate courses (Park 1996: 49).

As Nancy Levit and others have shown, women are more often called upon to do the "invisible work" of sustaining the academic community activities such as student advising and committee work (Levit 2001: 784). As faculty, childcare, and housekeeping remain the purview of women in the academic household - and it is undervalued labor. A preponderance of undergraduate institutions, from Regents bylaws to state legislatures, still mouth the platitudes that "teaching is our number one priority" at the same time that they sustain the practice of tenure and maintain a pecuniary reward structure almost exclusively on the basis of research.

While on one level Women's Studies as a field is surely feminized, in Veblen's description its marginalization along with the delayed and sometime outright failure of its insights to be incorporated into the body of knowledge in various disciplines may be explained by the delegitimation that comes with women doing "unfeminine" work. Because Women's Studies deals with the unfolding of the learner's own cognitive interests - of women themselves, it is in this sense "unfeminine" and hence unacceptable for enquiry for women. Women who study have proven themselves to be "unexceptional" and hence unacceptable much like Pizan had done centuries ago.

Finally, the drift of pecuniary culture has permeated the culture of higher education in a way that would surely have been evident to Veblen. As Linda Hutcheon, former president of the Modem Language Association, has pointed out, the mode of professional discourse adopted by the adepts in the higher learning mimics most clearly the competitive model of the market (Hutcheon 2003). The adopted mode of discourse, she points out, is one of combat and conflict - a mode of discourse that is perhaps nowhere as evident as that of the discipline charged with rationalizing competition economics. As anyone who has ever attended the American Economic Association meeting will observe, individuals present "arguments" which are typ- 
ically attacked by "discussants," followed by questions which often are not really questions at all but statements intended to demonstrate the prowess and status of the questioner. Instead, we could envision an entirely different mode of discourse based upon thoughtful exchanges constructively intended to expand discussion, perhaps build consensus, or contribute to the full exposition of a topic or question (Keller 1985; Harding 1986).

\section{Conclusion}

Where allowed to function outside the constraints of ownership in its expression of marriage - that is, in the few professional jobs that women were legitimately allowed in the late nineteenth century, Veblen argues that women provide an example of learning that eschews honorific attachments. It is interesting that while Veblen finds most activity in the higher learning taken up by invidious activities of a ceremonial nature, he identifies the methods and ideals of kindergarten - the purview of women - as praiseworthy. According to Veblen, such instruction is primarily directed towards proficiency in the employment of impersonal facts by women who are "ill at ease under the pecuniary code of reputable life" (Veblen [1899] 1998: 389). Neither driven by the ceremonial imperatives of the priestly class nor the pecuniary drive of consumer culture, Veblen sees women as teachers as a model of matter-of-fact learning.

In the end, Veblen argues that the introduction of women in the process of knowledge production might have wide-spread implications. Veblen concludes:

In this way it appears that, by indirection, the institution of a leisure class here again favors the growth of a non-invidious attitude, which may, in the long run, provide a menace to the stability of the institution itself, and even to the institution of individual ownership on which it rests.

(Veblen [1899] 1998:390)

In this somewhat oblique reference, Veblen suggests that the leisure class itself may be threatened by the spread of non-invidious learning, such as that which women propound in primary education. Moreover, he suggests that this may also serve to undermine the "institution of individual ownership" upon which it rests - ownership that, in its earliest form, Veblen describes as ownership of women by men (Veblen [1899] 1998: 22).

More recently, the growing number of women presidents at top universities introduces the possibility for further change as well. As the appointment of Drew Gilpin Faust as the first female President of Harvard University demonstrates, at least a few women have access to positions of influence. Whether those women are able to use their influence to pave the way for others to gain a full voice in the higher learning remains to be seen. While the true seat of power in the university system remains in the hands of the tenured full professors and the tenure system itself is under significant threat, the democratization of high administrative posts is underway. 
Although the institution of the higher learning has in many ways successfully resisted change, the consequence of women gaining an authoritative voice in the higher learning could not be more revolutionary. The inclusion of women in the higher learning could alter existing values, threatening not only the patriarchy of knowledge, but patriarchy in other institutions that distribute power in society. It is little wonder, then, that there remains such strong resistance to women's inclusion as writers of the canon in the process of knowledge production.

\section{Notes}

1 See UNESCO, Institute for Statistics, 2005 Report and USAID reporting of UNESCO statistics at http://qesdb.usaid.gov/cgi-bin/broker.exe? program=gedprogs.ged theme une 2.sas\& service=default\&sscode=UNE530538+\&cocode=ALL (accessed February $22,2007)$. Statistics measure the number of females enrolled in tertiary education expressed as a percentage of total tertiary enrollment. Enrollment includes students of all ages in both public and private schools.

2 As Martha Nussbaum (2003) shows, despite advances in much of the industrialized world, education for women remains a challenge in many parts of the world.

3 For example, in 2000 the University of Oslo implemented a plan to improve gender diversity among faculty by reserving 12 full or associate professorships for female candidates. In January 2003, the European Free Trade Association Court ruled that it was illegal for the University of Oslo to reserve faculty positions for women. See Chronicle of Higher Education, World Beat, "Court Bans Female-Professor Quota at U. of Oslo," February 28, 2003.

4 It is indeed telling that Lady Reason holds a mirror as a symbol of self-knowledge in an effort "to demonstrate clearly and to show both in thought and deed to each man and woman his or her own special qualities and faults ..." (Pizan [1431] 1982: 9).

5 Quoted in Pizan [1431] (1982: xxxvi).

6 Despite this, Pizan and others did not attack men directly, but male bias. As this quote from Mary Tattle-well and Joane Hit-him-Home argues, "We do not menace the men, but their minds; not their persons, but their pens; the horridness of their humors, and the madness of their muses: which indeed towards us have been insupportable and intolerable ..." (see Tattle-well and Hit-him-Home 1640: 109-110.)

7 See, for example, Thomas Kuhn, The Structure of Scientific Revolutions (1962), Peter Berger and Thomas Luckmann, The Social Construction of Reality: a Treatise in the Sociology of Knowledge (1966), Paul Feyerabend, Against Method: Outline of an Anarchistic Theory of Knowledge (1975), Edward S. Herman and Noam Chomsky, Manufacturing Consent: The Political Economy of the Mass Media (1988), and for a far different and more recent discussion see Steve Fuller, Philosophy, Rhetoric and the End of Knowledge: The Coming of Science and Technology Studies (1993).

8 For a full discussion of the role of gender identities and their importance in economics see Pat Hudson, "The historical construction of gender: reflections on gender and economic history," in Frontiers in the Economics of Gender, ed. Francesca Bettio and Alina Verashchagina (London and New York: Routledge, 2008) [this volume].

9 Calculation by Elizabeth Moorhouse based upon AAUP data on Category I institutions and status as measured by Barron's Profiles of American Colleges. Regression run with dependent variable of percentage of women faculty at school " $\mathrm{i}$ " and selectivity categories as independent variables. 


\section{References}

Astell, M. (1730) Some Reflections upon Marriage, 4th edn., London: Printed for William Parker.

Bell, S. G. (1976) “Christine de Pizan (1364-1430): Humanism and the Problem of a Studious Woman," Feminist Studies 3 (3/4): 173-184.

Berger, P. and Luckmann, T. (1966) The Social Construction of Reality: a Treatise in the Sociology of Knowledge. Garden City, NY: Doubleday.

Britz, J. D. (2006) “To All the Girls I've Rejected," The New York Times, March 23, 2006.

Chronicle of Higher Education, World Beat, "Court Bans Female-Professor Quota at U. of Oslo," February 28, 2003.

Dimand, M. A., Dimand, R. W. and Forget, E. L. (1995) Women of Value: Feminist Essays on the History of Women in Economics. Aldershot, UK: Edward Elgar.

Drake, J. (pseudonym) [1696] (1970) An Essay in Defence of the Female Sex. New York: Source Book Press.

Eliot, C. (1874) "Remarks of President Eliot of Harvard College before the Trustees of the Johns Hopkins University," in bind labeled "Johns Hopkins University 1874," Special Collections Holdings, The Ferdinand Hamberger, Jr. Archives.

Feyerabend, P. (1988) Against Method: Outline of an Anarchistic Theory of Knowledge. Atlantic Highlands, NJ: Humanities Press.

Freeman, J. (1969) “Women on the Social Science Faculties Since 1892" Paper delivered at the Political Science Association Conference, Winter 1969. http://jofreeman.com/ academicwomen/ucl892.htm (Accessed February 22, 2007).

Fuller, S. (1993) Philosophy, Rhetoric and the End of Knowledge: The Coming of Science and Technology Studies. Madison, Wisconsin: University of Wisconsin Press.

Harding, S. (1986) The Science Question in Feminism. Ithaca: Cornell University Press.

Harding, S. (1991) Whose Science? Whose Knowledge?: Thinking from Women's Lives. Ithaca: Cornell University Press.

Harding, S. (1993) "Rethinking Standpoint Epistemology: What Is 'Strong Objectivity?'“ in L. Alcoff and E. Potter (eds.) Feminist Epistemologies. London: Routledge.

Herman, E. S. and Chomsky, N. (1988) Manufacturing Consent: The Political Economy of the Mass Media. New York: Pantheon Books.

Hoffer, T. B., Sederstrom, S., Selfa, L., Welch, V., Hess, M., Brown, S., Reyes, S., Webber, K. and Guzman-Barron, I. (2003) Doctorate Recipients from United States Universities: Summary Report 2002. Chicago: National Opinion Research Center.

Hutcheon, L. (2003) "Rhetoric and Competition: Academic Agonistics," Common Knowledge, 9 (I): 42-49.

Jacobs, J. A. (1996) "Gender Inequality and Higher Education," Annual Review of Sociology, 22: 153-185.

Jordansson, B. (1999) The Politics of Gender Equality: The Encounter between Political Intentions and the Academy in the "Tham Professorships," A Report from The Swedish Secretariat for Gender Research. Goteborg, Sweden. http://www.genus.se/digitalAssets/285 report.pdf (Accessed February 22, 2007).

Kanter, R. M. (1977) Men and Women of the Corporation, New York: Basic Books.

Kelly, J. (1982) "Early Feminist Theory and the 'Querelle des Femmes,' 1400-1789," Signs: Journal of Women in Culture and Society, 8 (1): 4-28. 
Keller, E. F. (1985) Reflections on Gender and Science. New Haven: Yale University Press.

Kuhn, T. (1962) The Structure of Scientific Revolutions. Chicago: The University of Chicago Press.

Levit, N. (2001) "Keeping Feminism in Its Place: Sex Segregation and the Domestication of Female Academics," The University of Kansas Law Review, 49 (4): 775-807.

Longino, H. E. (1990) Science as Social Knowledge: Values and Objectivity in Scientific Inquiry. Princeton: Princeton University Press.

Lopez-Claros, A. and Zahidi, S. (2005) “Women's Empowerment: Measuring the Global Gender Gap," World Economic Forum 2005. Geneva, Switzerland. http://ncwo-online.org/data/images/WorldEconomicForum.pdf (Accessed February 22, 2007).

May, A. M. (1998) “Women and the Higher Learning in America: Veblenian Insights on the Leisure of the Theory Class," in D. Brown (ed.) Thorstein Veblen for the TwentyFirst Century. Northampton, MA: Edward Elgar.

May, A. M. (2006) "'Sweeping the Heavens for a Comet': Women, the Language of Political Economy, and Higher Education in the US," Feminist Economics, 12 (4): 625-640.

Mazón , P. M. (2003) Gender and the Modern Research University: The Admission of Women to German Higher Education, 1865-1914. Stanford, CA.: Stanford University Press.

Ministry of Children and Family Affairs (2000) Mainstreaming of Gender Equality in Norway. Oslo, Norway.

Moore, K. M. and Sagaria, M. A. D. (1991) "The Situation of Women in Research Universities in the United States: Within the Inner Circles of Academic Power," in G. P. Kelly and S. Slaughter (eds.) Women's Higher Education in Contemporary Perspective. Netherlands: Kluwer Academic Publishers.

Nordic Research Board (NORBAL) (2005) "Statistics on awarded doctoral degrees and doctoral students in the Baltic countries." http://english.nifustep.no/norbal I/eng/ startpage (Accessed February 22, 2007).

Nussbaum, M. (2000) Women and Human Development: The Capabilities Approach. Cambridge: Cambridge University Press.

Nussbaum, M. (2003) “Women's Education: A Global Challenge," Signs: Journal of Women in Culture and Society, 29 (2): 325-355.

Park, S. M. (1996) “Research, Teaching, and Service: Why Shouldn't Women's Work Count?" The Journal of Higher Education, 67 (I): 46-84.

Pizan, C. [1431] (1982) The Book of the City of Ladies. Translated by Earl Jeffrey Richards. New York: Persea Books.

Schibanoff, S. (1983) "Comment on Kelly's "Early Feminist Theory and the Querelle des Femmes, 1400-1789"," Signs: Journal of Women in Culture and Society, 9 (2): 320-326.

Sen, A. (1999) Development as Freedom. New York: Alfred A. Knopf.

Smith College Archives. http://www.smith.edu/collegerelations/traditions.php (Accessed February 22, 2007).

Tattle-well, M. and Hit-him-Home, J. (pseudonyms) (1640) The Women's Sharpe Revenge: or an answer to Dir Seldome Sober that write those railing pamphelets called the Iuniper and Crabtree lectures, London. Early English Books Online.

Tullberg, R. M. (1998) Women at Cambridge. Cambridge, England: Cambridge University Press. 
UNESCO, Institute for Statistics, 2005 Report and USAID reporting of UNESCO statistics. http://qesdb.usaid.gov/cgibin/broker.exe? program=gedprogs.ged theme une 2.sas\& service $=$ default\&sscode $=U N E 530538+\&$ cocode $=$ ALL (Accessed February 22,2007$)$.

Veblen, T. [ 1899] (1998) The Theory of the Leisure Class. Amherst, New York: Prometheus Books.

Veblen, T. (1917) An Inquiry Into the Nature of Peace and the Terms of its Perpetuation. New York: B. W. Huebsch.

Veblen, T. [1918] (1993) The Higher Learning in America. New Brunswick, New Jersey: Transaction Publishers.

Walsh, M. R. (1977) "Doctors Wanted: No Women Need Apply:" Sexual Barriers in the Medical Profession, 1835-1975. New Haven: Yale University Press.

Zimmer, A. (2003) Women in European Universities Final Report 2000-2003. Münster, Germany: Westfälische Wilhelms-Universität. http://www.goodfood-project.org/ www/Gender/FinalReport Zimmer 20.11.2003.pdf (accessed February 22, 2007). 